\title{
Foreign exchange exposure: evidence from the U.S. insurance industry
}

\author{
Donghui $\mathrm{Li}^{\mathrm{a}, *}$, Fariborz Moshirian ${ }^{\mathrm{a}}$, Timothy $\mathrm{Wee}^{\mathrm{b}}$ and Eliza $\mathrm{Wu}^{\mathrm{a}}$ \\ ${ }^{a}$ School of Banking and Finance, The University of New South Wales, Sydney, Australia \\ ${ }^{b}$ Equity capital markets, Citigroup Global Markets Asia Ltd, Hong Kong
}

This version: 6 January 2008

\begin{abstract}
We study the foreign exchange exposure of US insurers. The evidence shows that no systematic difference exists in the currency risk profiles of life and non-life segments within the insurance industry. This suggests that life and non-life insurers have similar risk exposure management strategies arising from similar risk pooling and financial intermediary functions. The empirical results reveal that a sizable proportion of U.S. insurers are exposed to foreign exchange movements against the seven largest U.S. trade partners in insurance services (U.K., Japan, Switzerland, Netherlands, France, Germany and Canada). Significant operational and size effects are also documented and we find that the frequency of foreign exchange exposure increases with time horizon.
\end{abstract}

JEL Classification: G22 ; F31

Keywords: Insurance; financial services; foreign exchange exposure; currency risk management

*Corresponding author. Tel.: +61 2 93855859; fax: + 61-2-93856347. E-mail addresses: donghui@unsw.edu.au (D. Li), f.moshirian@unsw.edu.au (F. Moshirian), timothy.wee@citigroup.com (T.Wee), e.wu@unsw.edu.au (E.Wu). 


\section{Introduction}

With the continued liberalization of international financial markets and the proliferation of trade in financial services, international insurance services are becoming increasingly important. Within the area of international financial services, the importance of detecting and measuring foreign exchange exposure for international risk management strategies is increasingly being recognized. Thus, we focus this study on the foreign exchange risk exposure of the US insurance industry, a key provider of international insurance services.

The existing multinational foreign exchange exposure literature centers on the impact of currency volatility on international trade, firm value and the use of derivatives and operational hedging strategies. For international financial services, besides the study by Li, Moshirian and Sim (2003) that discusses factors that contribute to the expansion of international trade in insurance services without reference to foreign exchange volatility, the current literature is concentrated around banks (for example, Choi and Elyasiani (1997), Chamberlain et al. (1997) and Martin and Mauer, 2003)) and far less attention has been devoted to non-bank financial institutions, such as insurance companies. This is alarming given that it is recognized that there are potentially different impacts of currency exposure between financial and non-financial firms (see Allayannis and Weston (2001)).

The few existing studies examining foreign exchange risk faced by insurers focus more on the use of derivative instruments for hedging and risk management and its determinants (Colquitt and Hoyt (1997), Hentschel and Smith (1997) and Cummins, Phillips and Smith (2001)) rather than specifically looking at the area of currency risk exposure. Foreign exchange risk is one of the many risks that U.S. insurers face. With the increased internationalization of insurance operations, insurers have begun to undertake greater investments in foreign securities, either as a 
means of realizing portfolio diversification benefits or to hedge foreign liabilities. Thus, detecting foreign exchange exposure in the U.S. insurance industry provides an important starting point in identifying the determinants of exchange rate risk exposure and for evaluating the impact of currency risks within international insurance services. This paper contributes to the literature by providing, for the first time, direct evidence documenting the extent of foreign exchange exposure in the insurance industry and specifically its life and non-life insurance segments.

Unlike previous aggregated studies on non-financial multinational firms (see Jorion (1990), Bodnar and Gentry (1993) and Chow, Lee and Solt (1997b)) that may not account for firm-specific trade linkages, this paper conducts individual firm level estimations to avoid the averaging effects arising from the grouping of firms across different industries. ${ }^{1}$ Khoo (1994) and Choi and Prasad (1995) also point out that the significance level of currency risk exposure decreases when calculated at a portfolio level. Furthermore, aggregation of firms implicitly assumes that there is no heterogeneity within the group. This potentially disguises firm-specific information such as operational and managerial differences, making the identification of significant currency exposure difficult and highly biased (Bartov and Bodnar (1994)). Furthermore, the potential estimation errors arising from investors' mispricing of currency exposure in stock returns is avoided by employing a cash flow based approach that can minimize the noise in foreign exchange exposure detection. Moreover, using a cash flow based methodology significantly contributes to the area of foreign exchange exposure management since a major reason firm managers seek to manage currency risk comes from their desire to control cash flow volatility (Bodnar et al. (1998)).

\footnotetext{
${ }^{1}$ More recently, Muller and Verschoor (2006, 2007a,b) examined foreign exchange exposure using individual firms within different industries to avoid the averaging effects across industries whilst providing a detailed comparison of the extent of foreign exchange risk exposures in different industries and regions.
} 
We find that there are no systematic differences in the foreign exchange risk profiles between life and non-life insurers. This demonstrates that both life and non-life insurers' finance and investment incomes are influenced by exchange rate uncertainty. This also suggests that life and non-life insurers have similar risk management strategies arising from similar risk pooling and financial intermediary functions. The empirical results reveal that a sizable proportion of U.S. insurers are exposed to foreign exchange movements to the seven largest U.S. trade partners in insurance services (these are: the U.K., Japan, the Netherlands, Switzerland, France, Germany and Canada according to the Bureau of Economic Analysis (2003) Survey of Current Business). We find the presence of both an operational effect and a size effect, suggesting that the geographic diversity of multinational insurers and their firm size correlates with increased hedging activity. This paper also finds that the frequency of foreign exchange exposure increases with the time horizon, thus corroborating with the idea that multinational firms prefer to use currency derivatives to hedge shorter-term transactional exposure over the longer-term economic exposure that is harder to assess.

The rest of this paper is organized as follows. Section 2 introduces the methodology used for detecting foreign exchange exposure across insurance firms. In Section 3, the empirical hypotheses are discussed. Section 4 details the data and sample used and Section 5 reports the main findings. Finally, conclusions are made in Section 6.

\section{Methodology to detect foreign exchange exposure}

Most of the existing US and non-US studies examine foreign exchange exposure relative to firm value, as measured by stock price returns (see Jorion (1990), Bodnar and Gentry (1993), 
Bartov and Bodnar (1994), Choi and Prasad (1995), He and Ng (1998), Bartram (2004), Muller and Verschoor (2006, 2007a,b) and references therein). This induces potential estimation difficulties in detecting foreign exchange exposure should investors not price the currency exposure correctly. This is made even more difficult given the asymmetry in information between corporate insiders and outsiders. The use of unanticipated operating income avoids this potential problem; additionally, it models the unexpected component of cash flows that would be due to foreign exchange volatility, which is the basis of foreign exchange exposure management by multinational firms’ managers.

This study employs a two-step OLS regression approach to estimate the extent to which U.S. insurance companies exhibit exchange rate exposure. The unanticipated operating income for each firm and the foreign exchange variable are first estimated using a seasonal random walk model and a log linear model respectively to remove potentially confounding effects on the exchange rate-cash flow relationship. These variables are then used in the main estimation model following the Almon (1965) distributed lag technique to find the frequency of detecting significant exchange rate exposures in insurers.

We employ Martin and Mauer's (2003) technique of purging the unanticipated income before adjustments $\left(U O I_{i t}\right)$ variable in the form of estimated residuals from a seasonal random walk model. We regress four-quarter lagged values of each sample insurance company's operating income before depreciation and foreign exchange adjustments on current operating income before adjustments. ${ }^{2}$

$$
O I_{i t}=\alpha_{i}+\theta_{i}(O I)_{i(t-4)}+\mu_{i t}
$$

\footnotetext{
${ }^{2}$ We also regressed 8-quarter lagged values of insurers' operating income to account for seasonal effects up to two years but these were rarely significant.
} 
Where $\alpha_{\mathrm{i}}$ is the mean of the seasonal difference for insurer $i$, which is the average annual trend in the data and is assumed to be constant. This seasonal trend model is a special case of an Autoregressive Integrated Moving Average (ARIMA) model where there is only one order of seasonal differencing, a constant and no other parameters. Because of the nature of the seasonal specification, one significant advantage of such a model is that it is relatively stable and will not be affected by sudden changes in the data within a one year period. The residuals $\left(\mu_{i t}\right)$ divided by the standard deviation form $U O I_{i t}$, the standardized unanticipated operating income variable which is used in the estimation model.

The $O I_{i t}$ variables for all insurance companies are first tested for the presence of unit roots. This ensures the stationarity of the residuals and consequently the $U O I_{i t}$ variables. Doing so protects the formalized estimation model from having spurious regression results. Where a company exhibits non-stationary $\mathrm{OI}_{i t}$, the first difference of the $O I_{i t}$ variable in equation 1 is used instead. Since the unanticipated component of operating income (i.e. the residuals of equation 1) is what this stage is estimating, doing so does not change our interpretation of the residuals for the first difference model, thus ensuring consistency across the whole sample of insurance companies.

Next we measure the foreign exchange variable, FOREX, using the residuals of equation 2 shown below. It represents the unexplained change in foreign exchange rates where the natural $\log$ of foreign exchange movement is modeled as a function of the contemporaneous natural log of interest rate differentials ${ }^{3}$ and economic output differentials (in local currencies). The use of a fundamentals-based regression overcomes the need to assume a dynamic lag structure in foreign exchange movements when there is no basis for seasonality. This is consistent with the use of

\footnotetext{
${ }^{3}$ Long-term government bond yields were used as short-term treasury bill rates are subject to central bank manipulations for effecting monetary policy.
} 
unanticipated change in exchange rates in the existing literature (see Jorion (1990), Chow, Lee and Solt (1997a and 1997b) and Martin and Mauer (2003)) and provides a suitable basis for examining the effects on insurance firms. We estimate the following model ${ }^{4}$ :

$$
\operatorname{LOG}\left(F X_{j t}\right)=a_{j t}+\phi_{1 j t} L O G\left(I R_{j t}\right)+\phi_{2 j t} L O G\left(O P_{j t}\right)+F O R E X_{j t}
$$

Where,

$$
\begin{aligned}
F X_{j t} & =\frac{E_{j t}}{E_{j(t-1)}} \\
I R_{j t} & =\frac{I N T_{j t}}{I N T_{U . S, t}} \\
O p_{j t} & =\frac{G D P_{j t} / G D P_{j(t-1)}}{G D P_{U . S, t} / G D P_{U . S,(t-1)}}
\end{aligned}
$$

To proxy foreign exchange movements, $F X_{j t}$ is used to represent the relative change in spot exchange rates, given by the ratio of $E_{j t}$, the exchange rate for country $j$ relative to the U.S dollar at time $t$ to $E_{j(t-1)}$. The $\mathrm{IR}_{\mathrm{jt}}$ variable represents the parity condition regarding spot interest rates given by the ratio of $I N T_{j t}$ and $I N T_{U . S, t}$, which are the long-term government bond yields for country $j$ and the U.S at time $t$ respectively. The $O P_{j t}$ variable acts as a proxy for the difference in the relative changes in economic output of country $j$ and the U.S. Here, $G D P_{j t}$ and $G D P_{U . S, t}$ are the level of real economic activity in country $j$ and the U.S respectively at time $t$. FOREX $X_{j t}$ represents the residuals of the estimated model (unexplained change in foreign exchange rates). ${ }^{5}$

\footnotetext{
${ }^{4}$ Stationarity tests were first conducted for the variables used and differences were taken for the IR variable in 3 out of 7 cases. Given that we rely on only the residuals from this equation, taking first differences does not qualitatively change our interpretations.

${ }^{5}$ We also estimated this model in a seemingly unrelated regression across the 7 currencies studied but this simply restricted the variation in the extent of foreign exchange exposure to different currencies for our sample of insurance firms.
} 
The model consists of estimating the sensitivity of unanticipated operating income before adjustments, $U O I_{i t}$, to contemporaneous and lagged foreign exchange variables, FOREX. The formalized model to be used here follows the Almon distributed lag structure and is presented as:

$$
U O I_{i t}=c_{i}+\sum_{q=0}^{L_{i}} \beta_{i q} F O R E X_{t-q}+\varepsilon_{i t}
$$

Where $U O I_{i t}$ is the standardized unanticipated operating income before adjustment for depreciation and foreign exchange gains or losses, as a proxy for cash flow for insurer $i$ in time period $t$; FOREX $X_{t-q}$ is the percentage change in the unexplained exchange rate factor in time period $t-q ; c_{i}$ is the intercept for insurer $i ; \beta_{i q}$ are foreign exchange exposure coefficients, which represent the sensitivity of cash flows to short term and long term exchange rate changes (to be estimated), for insurer $i$ with $q$, quarters 0 through $L$. Here, $\beta_{i q}$ follows the Almon technique where $L_{i}$ is the lag length, up to 12 quarters as determined by the Akaike information criterion (AIC) for insurer $i$; $\varepsilon_{i t}$ is the stochastic error term.

As it is very difficult to know the true shape of the FOREX variable, a priori this study follows Martin and Mauer (2003) in using a third degree polynomial "which is sufficiently flexible to allow for typical lag patterns” (p.858). Thus, it is assumed that the $\beta_{i q}$ 's can be modeled by:

$$
\hat{\beta}_{i q}=\hat{a}_{0 i}+\hat{a}_{1 i}(q)+\hat{a}_{2 i}(q)^{2}+\hat{a}_{3 i}(q)^{3}
$$

Substituting equation 4 into equation 3 , the model used for estimation is as below:

$$
U O I_{i t}=\alpha_{i}+a_{0 i} Z_{0 i t}+a_{1 i} Z_{1 i t}+a_{2 i} Z_{2 i t}+a_{3 i} Z_{3 i t}+\varepsilon_{i t}
$$

Where 


$$
\begin{aligned}
& Z_{0 i t}=\sum_{q=0}^{L} \text { FOREX }_{i(t-q)}=\text { FOREX }_{i t}+\text { FOREX }_{i(t-1)}+\ldots+\text { FOREX }_{i(t-L)} \\
& Z_{1 i t}=\sum_{q=0}^{L}(q) \text { FORE }_{i(t-q)}=(1) \text { FOREX }_{i(t-1)}+(2) \text { FOREX }_{i(t-2)} \ldots+(L) \text { FOREX }_{i(t-L)} \\
& Z_{2 i t}=\sum_{q=0}^{L}(q)^{2} \text { FOREX }_{i(t-q)}=(1)^{2} \text { FOREX }_{i(t-1)}+(2)^{2} \text { FOREX }_{i(t-2)}+\ldots+(L)^{2} \text { FOREX }_{i(t-L)} \\
& Z_{3 i t}=\sum_{q=0}^{L}(q)^{3} \text { FORE }_{i(t-q)}=(1)^{3} \text { FOREX }_{i(t-1)}+(2)^{3} \text { FOREX }_{i(t-2)}+(3)^{3} \text { FOREX }_{i(t-3)}+\ldots+(L)^{3} \text { FOREX }_{i(t-L)}
\end{aligned}
$$

Using $U O I_{i t}$, the coefficients $a_{0}-a_{3}$ in equation 5 are easily obtained via the usual OLS procedure. These coefficients are then used to calculate the $\beta_{i q}$ coefficients of the formalized model, equation 3.

\section{Hypotheses tested}

Along with identifying the extent of currency exposure within the US insurance industry and its life and non-life segments, this study empirically tests three main hypotheses to better understand foreign exchange exposure in US insurance firms.

\subsection{Operational scope effects: domestic and international insurers}

H1: Domestic insurance firms exhibit higher frequencies of foreign exchange exposure than international insurance firms.

Much of the literature looking at foreign activity and foreign exchange exposure utilizes accounting-based measures to proxy operational exposure (Chamberlain et al. (1997), Allyannis and Weston (2001) and Choi and Kim (2003)). More recently, Martin and Mauer (2003) grouped U.S. banks according to whether they are domestic or internationally focused. The difference between these methods is that where the former method estimates the extent to which operational 
scope impacts on foreign exchange exposure, the latter allows us to identify systematic differences in the type (domestic versus international) of operations rather than the scope.

Chamberlain et al. (1997) look at cross-sectional determinants of U.S. banks' foreign exchange exposure estimates using accounting-based measures of currency risk. To proxy operational scope and hence foreign activity, they use net foreign assets and find a negative correlation with the estimated foreign exchange exposure coefficients. This implies that the larger the short foreign currency position, the greater the foreign exchange exposure. Allayannis and Weston (2001) classify firms into two samples depending on the existence of foreign sales. They find that for the firms with foreign sales, users of foreign currency derivatives do exhibit higher mean and median levels of Tobin's $Q$, reflecting higher firm values. Allayannis et al. (2001) further find that firms with greater geographical scope tend to use more financial rather than operational hedges, implying lower levels of foreign exchange exposure for international firms compared to domestic firms.

In terms of operational scope, conventional wisdom would suggest that internationally focused firms would face foreign exchange exposure whereas domestic firms would not - this may be true for direct exposure. When indirect exposure to foreign exchange is considered, domestic firms may also be faced with foreign exchange exposure. These include the competitive effects of foreign firms, and an indirect cost exposure should the supplier of a domestic firm be exposed to direct foreign currency movements and pass on cost increases arising from a negative movement in exchange rates. Hentschel and Smith (1997), Chamberlain et al. (1997) and Martin and Mauer (2003) agree that insurance companies and banks are indeed exposed to such indirect influences. This exposure arises from the nature of their assets, which are particularly sensitive to insolvency risk and could be dependent on the level of foreign exchange exposure. 
The existing literature suggests that foreign exchange movements do have an impact on domestic companies (Jorion (1990) and Martin and Mauer (2003)). In particular, Martin and Mauer (2003) find that U.S. domestic banks exhibit more foreign exchange exposure than U.S. international banks. This supports the hypothesis of international firms hedging more in light of the more direct transactional and economic exposure that they face. Martin and Mauer (2003) place the foreign exchange risk of US banks in the view of both direct and indirect exposures. Where international insurers face both forms of exposure, domestic insurers are indirectly exposed to adverse foreign exchange movements via channels such as the solvency of its policyholders, reinsurance, and foreign competitive effects. Hence, we test whether the frequencies of foreign exchange exposure are higher for domestic insurers than international insurers.

\subsection{Size effects and foreign exchange exposure}

H2: Large (Small) insurers will exhibit lower (higher) frequencies of foreign exchange exposure than small (large) insurers.

The premise behind the size effect of firms stems from them reaping the benefits of economies of scale and scope to achieve informational and cost savings in foreign exchange exposure management.

Chow, Lee and Solt (1997b) found that larger firms are better able to manage economic exposure to foreign exchange fluctuations by implementing operational hedges. Unlike transaction exposure management, this constitutes managing foreign currency inflows and outflows such that the net exposed amount is minimized. They credit this to operating, financial 
or informational scale economies that make it easier and more beneficial for larger firms to undertake the hedge.

Nance, Smith and Smithson (1993) find that larger firms tend to hedge more. Allayannis and Weston (2001) suggest that large non-financial firms are more likely to use currency derivatives than small firms given the potentially large start up fixed costs of hedging. The authors also find a positive relationship between currency derivative usage and firm value for internationally oriented firms. This is consistent with the findings of Chamberlain et al. (1997) where increased derivative usage leads to lower foreign exchange exposure.

For financial firms, the literature surrounding size and foreign exchange exposure remains unclear. Chamberlain et al. (1997) find that the largest U.S. banks generally exhibit larger foreign exchange exposures. This potentially stems from the role of many of these large banks as dealers in derivative contracts (this is also potentially true for insurers as some also act as market makers in derivatives) and suggests that the banks in their sample use their position as dealers in derivatives to undertake speculative positions. Thus, their finding contradicts the traditional view that larger derivative usage should correlate with lower foreign exchange exposure.

Specific to the insurance sector, Colquitt and Hoyt (1997) suggest that the size of an insurer could potentially have a positive or negative effect on the use of derivatives. However, Cummins et al. (2001) document that larger insurers participate more actively in derivative markets and have more derivative holdings than smaller ones. They conclude that derivatives activities are subject to scale economies in the insurance industry. Hence, informational economies and cost economies of scale could lead to a positive relationship with insurers' size and use of derivatives (and they should be less exposed to foreign currency risks). On the other hand, smaller firms are likely to face higher financial distress costs so they may have more incentives to hedge than 
larger firms. Given that hedging reduces the volatility of firm value and the likelihood of facing bankruptcy, the use of financial derivatives for hedging purposes may also be inversely related to firm size.

Based on the majority of findings on the size effects in the hedging of foreign exchange exposure, we hypothesize that large (small) insurers will exhibit lower (higher) frequencies of foreign exchange exposure than small (large) insurers due to more (less) hedging activities arising from informational and cost economies of scale in foreign exchange exposure management.

\subsection{Time horizon effects: short term and long term exposure}

H3: Insurers exhibit more frequent (significant) long-term rather than short-term foreign exchange exposures.

Chow, Lee and Solt (1997b) find that the foreign exchange exposure of the firms in their sample increases with the time horizon. This is because the total impact of currency movements on a firm's future cash-flows can only be correctly evaluated by investors in the long run and it is likely that investors will systematically make errors when assessing the impact of currency movements on firm value in the short-run (see Muller and Verschoor (2006 and 2007b) for further discussions). They also suggest this indicates short-term foreign exchange exposure effects are mitigated by the use of short-term transaction exposure strategies comprising the use of forwards, futures, swaps, options and other derivatives. As longer-term exposure is based more on economic exposure management using operational hedges and is more difficult to undertake, such exposure would thus be more pronounced. In a survey of Finnish Industrials, Hakkarainen et al. (1998) also find that there exists a much greater propensity to hedge transaction exposure over long-term economic exposure. 
Nguyen and Faff (2003) document the existence of both long and short-term exposure for Australian companies and link the time horizon nature of these exposures with the use of foreign currency derivatives. Their findings show that Australian firms are generally more exposed to long-term currency movements. They further find evidence that this in part could be due to the increased effectiveness of foreign currency derivatives in managing short-term currency movements over the longer-term economic exposure.

Hence, we expect insurers to show significantly more frequent long-term rather than shortterm foreign exchange exposures. Consistent with Martin and Mauer (2003), this study classifies short-term exposure as those insurers with optimal lags of 4 quarters or less ( $<1$ year) and longterm exposure as insurers with optimal lags of 8 or more ( $\geq 2$ years) based on the AIC statistic of the polynomial distribution model, equation 3.

\section{Data and sample selection}

Sample quarterly data between the years 1990 to 2003 are used in this study. Operating incomes are obtained from the Research Insight database by COMPUSTAT. One of the reasons why we have used data from COMPUSTAT is that it grasps the homogeneity of the operating income measures of each firm across industries. The cash flow proxy used in this paper according to COMPUSTAT, is defined as "Sales (net) minus Cost of Goods Sold and Selling, General, and Administrative expenses before deducting Depreciation, Depletion and Amortization”. The study by Martin and Mauer (2003) on foreign exchange exposures of US banks also used COMPUSTAT as their source of data. ${ }^{6}$

\footnotetext{
${ }^{6}$ We cross-checked the data with other data sources and verified that the relevant numbers are not quantitatively different.
} 
Companies are identified according to their insurance GIC industry group code, and comprise insurance brokers, life and health, multi-line, property-casualty, and reinsurance companies. Under this classification, 210 companies are identified. In addition to the GIC industry group classification, the insurance companies are filtered according to availability of data; in this case, companies with more than 30 quarterly observations are used leaving 73 nonbroker insurers in the final sample. ${ }^{7}$ Exchange rate data (end of period) ${ }^{8}$, long-term government bond yields and Gross Domestic Product (GDP) figures are taken from the International Financial Statistics database ${ }^{9}$. For countries that switched to using the Euro in 1999 (France, Germany and Netherlands), the exchange rates for these years are adjusted using the fixed exchange rate between the Euro and the domestic currency as obtained from the European Central Bank. To identify large companies versus small companies, the median asset value of each company is considered and asset sizes of greater than US\$1 billion are classified as large. ${ }^{10}$ Companies are also classified under domestic or international according to data from the geographic segment of COMPUSTAT. For fiscal years ending after December 15, 1977, firms are required to report geographic segment data. These firms must report information for segments with assets, sales or profits that exceed 10 percent of consolidated totals. Where foreign sales data is not available, these companies are classified as being domestically focused.

\footnotetext{
${ }^{7}$ We excluded 11 insurance brokers with sufficient time-series data from our analysis as their business operations are substantially different from other insurance firms.

${ }^{8}$ Following Chamberlain et al. (1997) and Martin and Mauer (2003), this study uses nominal exchange rates. According to Choi and Kim (2003), for industrialized countries, the random walk and efficient markets hypotheses make both real and nominal exchange rates acceptable. The exchange rates for the Netherlands, France and Germany are replaced with the euro from the beginning of 1999 corresponding with their adoption.

${ }^{9}$ This is with the exception of France and Canada, where complete real GDP figures were unavailable. These figures are instead obtained from the OECD published Quarterly National Accounts available at www.sourceoecd.org.

${ }^{10}$ This cutoff for large firms corresponds to the 47 th percentile in our sample. As a robustness check, we also split the sample firms at the median and there were no qualitative differences in our results.
} 
The currencies chosen for this study represent those of the main trading partners of the U.S. in terms of FDI in insurance (see Table 1). Using a measure of insurance activity given by the total average U.S inflows and outflows of FDI in insurance for the years 2002 and 2001, it can be seen that the seven countries in this study make up more than 64.4 percent of total insurance activity with the U.S. Out of this, outflows dominate inflows with these seven countries accounting for a respectable 84.1 percent of overall outflows out of the U.S. This is in comparison to the smaller but no less significant figure for average total inflows of 50.4 percent. Globally, these markets represent almost 79 percent of world insurance premium, with the U.S. market alone accounting for 38.1 percent.

$<$ Insert Table 1>

\section{Main findings}

\subsection{Overall results: all insurance companies}

The main focus of this study is to investigate the pervasiveness of foreign exchange exposure among U.S. insurance companies. Table 2 reports the degree of significant foreign exchange exposure for U.S. insurers. As can be seen, substantial proportions of US insurers are exposed to foreign exchange exposure. Specifically, 73 percent are exposed to the British Pound, 71 percent to the Japanese Yen, 51 percent to the Swiss Franc, 42 percent to the Dutch Guilder, 55 percent to the French Franc, 59 percent to the Deutsche Mark and 37 percent to the Canadian Dollar. Importantly, 100 percent of insurers studied are exposed to at least one of these currencies. This is not surprising given that these currencies represent the seven most significant trading partners with the U.S. in terms of insurance. The high frequency of foreign exchange 
exposure further serves to highlight the importance of these currency values to the cash flows of U.S. insurance companies. Compared to the banking literature, these frequencies are consistent with Choi and Elyasiani (1997) but proportionately higher than Chamberlain et al. (1997), Choi and Kim (2003) and Martin and Mauer (2003) amongst others. This suggests that among financial institutions, operational and cash flow exposure is higher for insurance companies than banks due to lower levels of financial and operational hedging. This result could also point to other systematic differences in the risk management and hence, risk profiles of insurers and banks.

$<$ Insert Table 2>

\subsubsection{Life and non-life insurers}

In Table 2 Panel A, we find that the extent to which non-life and life insurers are significantly exposed to all 7 currencies is actually quite similar. The two sample $\mathrm{Z}$ test of population proportions is used to compare the exposures of life with non-life insurers. Despite lower levels of specialization in non-life insurers, the results clearly indicate that their currency exposure is not significantly greater than those of life insurers. This remains true in further sample splits on the basis of operational focus - there are no statistically significant differences in exposure proportions between domestic and international life and non-life insurers. Taken together, the results suggest that the underlying transactional and operational exposures of life and non-life insurers are in fact similar.

\subsection{Operational scope effects}

In comparing domestic with international insurers in Panel B of Table 2, we find that domestic insurers do show statistically more frequent foreign exchange exposures than international insurers to the British Pound and Dutch Guilder. This is consistent with the findings 
of Allayannis and Weston (2001) and Martin and Mauer (2003), and suggests that insurers with greater international operational exposures are more willing to hedge foreign exchange exposure given the recognition of their direct transactional and economic exposure to adverse changes in exchange rates. As a robustness check, we also controlled for size effects by splitting the domestic and international insurers into small and large firms. Our findings suggest that international insurers are more likely to hedge foreign exchange exposure in light of greater direct operational risk to cash flows.

\subsection{Size effects: currency exposure of small and large insurers}

As expected, in Panel C of Table 2 we find that large (small) insurers have proportionately lower (higher) frequencies of foreign exchange exposure. The one-tail $\mathrm{Z}$ test results provide some support for the size effect as documented in existing studies (Chow, Lee and Solt (1997b), Colquitt and Hoyt (1997) and Cummins et al. (2001)). We find that small insurers are statistically more exposed to both Swiss and Canadian currencies than large insurers. The lower frequencies of foreign exchange exposure for larger insurers supports the notion that large insurers benefit from informational and cost economies which results in increased hedging strategies to manage unexpected movements in these bilateral exchange rates.

\subsection{Time horizon effects: short and long term exposure}

Table 3 presents the results concerning the time horizon effect on foreign exchange exposure for all insurers, domestic and international insurers as well as the small and large insurers.

$<$ Insert Table 3 here $>$

Consistent with Chow, Lee and Solt (1997b), Nguyen and Faff (2003), Martin and Mauer (2003), Muller and Verschoor (2006, 2007a,b) and references therein, this study finds that the 
frequency of foreign exchange exposure increases with the length of the time horizon. This supports the theory that firms tend to be more at risk from long-term exposure given the ease with which short-term exposure can be hedged using currency derivatives. One-tail Z tests of proportions indicate that for nearly all currencies studied, firms with long-term optimal lags show significantly greater frequencies of foreign exchange exposure than those with short-term optimal lags. In addition, these results corroborate with the bulk of the existing literature and suggest that insurers are more prone to long term operating exposure instead of the more shortterm transaction exposure, which can be more easily assessed and hedged with derivatives. These results are pervasive and they also hold for domestic and small and large insurance firms.

Taken together, the results show that the frequency of foreign exchange exposure unambiguously increases with the time horizon. We find support for the theory that longer-term foreign exchange exposure requires economic exposure management via operational or natural hedges (Chow, Lee and Solt (1997b)). For firms with international exposure, such hedges are much harder to undertake compared with using currency derivatives for transactional exposure management in light of the difficulty in ascertaining the value to hedge, as well as significant costs associated with the restructuring of foreign currency inflows, outflows and foreign currency assets and liabilities. Domestic insurers also show significantly more frequent longterm exposure than short-term exposure. This indicates that the same difficulty exists for domestic insurers given the difficulty in assessing long-term exposure without the option of undertaking operational hedging via the restructuring of foreign assets, liabilities and cash flows. In addition, the channel of foreign exchange exposure would be more indirect than direct, making the task of domestic risk managers even more difficult. 


\section{Conclusions}

This paper extends the existing literature on foreign exchange exposure by documenting its pervasiveness in the U.S. insurance industry. In addition, several hypotheses are tested to determine if operational scope, firm size and the time horizon of exposure have an impact on the patterns of foreign exchange exposure faced by U.S. insurers. The existing literature predominantly looks at foreign exchange exposure on an aggregate level, which potentially masks the identification of currency exposure. This firm-level study allows for the heterogeneous nature of individual insurer's economic linkages based on the methodology employed by Martin and Mauer (2003) for banks with some innovations suited to studying insurance firms.

The results highlight the importance of exchange rate exposure management within the U.S. insurance industry. A large proportion of insurers show significant foreign exchange exposure to the each of the seven major currencies studied and to at least one of these currencies. The potential existence of systematic differences in the foreign exchange exposure of life and non-life insurers is also investigated for the first time. This paper finds that there does not appear to be any difference in the exposure frequencies detected, suggesting similar risk exposure management strategies between life and non-life insurers.

Evidence supporting several key theories from the existing literature on foreign exchange exposure and currency risk management is provided in this paper. The operational scope of U.S. insurers does affect their level of foreign exchange exposure. The significance of foreign exchange exposure to domestic and international insurers is found and the presence of both direct and indirect exposure faced by insurers as found by Martin and Mauer (2003) for banks is verified. For insurers, this is potentially due to the marketing of innovative bank-like products by insurers such as foreign currency endowment policies and other investment products that offer 
investors exposure to foreign markets. In comparing between domestic and international insurers, domestic insurers show significantly greater frequencies of foreign exchange exposure. This supports the theory that international firms tend to hedge more given that their exposure is more easily identified. Domestic firms on the other hand exhibit greater economic exposure since the indirect exposure they face are even more difficult to ascertain and execute.

Regarding the size effect, the lower frequencies of foreign exchange exposure for larger insurers support the theory that large insurers benefit from informational and cost economies which result in superior hedging strategies (and risk management overall) to manage unexpected movements in these bilateral exchange rates.

In studying foreign exchange exposures in the short and long-term horizons, we find that the number of significant foreign exchange exposures faced by insurers increases with the time horizon. In accordance with the existing literature, this result suggests that U.S. insurers tend to focus more on hedging short-term transactional exposure with derivatives rather than longerterm operational exposure. It corroborates with the theory that the management of short-term foreign exchange transaction exposure is the more popular choice among financial risk managers. 


\section{References}

Allayannis, G., Weston, J., 2001. The use of foreign currency derivatives and firm value. Review of Financial Studies 14(1), 243-276.

Allayannis, G., Ihrig, J., Weston, J., 2001. Exchange-rate exposure: financial vs operating strategies. American Economic Review Papers and Proceedings 91, 391-398.

Almon, S., 1965. The distributed lag between capital appropriations and expenditures. Econometrica 33, 178-196.

Bartov, E., Bodnar, G.M., 1994. Firm valuation, earnings expectations and the exchange-rate exposure effect. Journal of Finance 49, 1755-1785.

Bartram, S., 2004. Linear and nonlinear foreign exchange rate exposures of German nonfinancial corporations. Journal of International Money and Finance 23(4), 673-699.

Bodnar, G.M., Gentry, W.M., 1993. Exchange-rate exposure and industry characteristics: evidence from Canada, Japan and the U.S. Journal of International Money and Finance 12, 2945.

Bodnar, G. M., Hayt, G.S., Marston, R.C., 1998. Wharton survey of financial risk management by U.S. non-financial firms. Financial Management 27, 70-91.

Bureau of Economic Analysis, 2003. Survey of current business 83(9), Washington DC.

Chamberlain, S., Howe, J.S., Popper, H., 1997. The exchange rate exposure of U.S. and Japanese banking institutions. Journal of Banking and Finance 21, 871-892.

Choi, J.J., Elyasiani, E., 1997. Derivatives exposure and the interest rate and exchange rate risks of U.S. banks. Journal of Financial Services Research 12, 267-286. 
Choi, J.J., Kim, Y.C., 2003. The asian exposure of U.S. firms: operational and risk management strategies. Pacific-Basin Finance Journal 11, 121-138.

Choi, J.J., Prasad, A.M., 1995. Exchange risk sensitivity and its determinants: a firm and industry analysis of U.S. multinationals. Financial Management 24, 77-88.

Chow, E.H., Lee, W.Y., Solt, M.E., 1997a. The exchange-rate risk exposure of asset returns. Journal of Business 70, 105-123.

Chow, E.H., Lee, W.Y., Solt, M.E., 1997b. The economic exposure of U.S. multinational firms. Journal of Financial Research 20(2), 191-210.

Colquitt, L.L., Hoyt, R.E., 1997. Determinants of corporate hedging behavior: evidence from the life insurance industry. Journal of Risk and Insurance 64(4), 649-671.

Cummins, J.D., Phillips, R.D., Smith, S.D., 2001. Derivatives and corporate risk management: participation and volume decisions in the insurance industry. Journal of Risk and Insurance 68(1), 51-91.

Hakkarainen, A., Joseph, N., Kasanen, E., Puttonen, V., 1998. The foreign exchange exposure management practices of finnish industrial firms. Journal of International Financial Management and Accounting 9(1), 34-57.

He, J., Ng, L.K., 1998. The foreign exchange exposure of Japanese multinational corporations. Journal of Finance 53(2), 733-753.

Hentschel, L., Smith, C.W., 1997. Risks in the derivatives markets: implications for the insurance industry. Journal of Risk and Insurance 64, 323-345.

Li, D., Moshirian, F., Sim, A., 2003. International financial services: IIT in insurance services. Journal of Risk and Insurance 70, 269-287. 
Jorion, P., 1990. The exchange-rate exposure of U.S. multinationals. Journal of Business 63, $331-345$.

Khoo, A., 1994. Estimation of foreign exchange exposure: an application to mining companies in Australia. Journal of International Money and Finance 13, 342-363.

Martin, A.D., Mauer, L.J., 2003. Exchange rate exposures of U.S. banks: a cash flow-based methodology. Journal of Banking and Finance 27, 851-865.

Muller, A., Verschoor, W.F.C., 2006. European foreign exchange risk exposure. European Financial Management 12(2), 195-220.

Muller, A., Verschoor, W.F.C., 2007a. Asian foreign exchange risk exposure. Journal of the Japanese and International Economies 21, 16-37.

Muller, A., Verschoor, W.F.C., 2007b. The Latin American exchange exposure of U.S. multinationals. Journal of Multinational Financial Management, forthcoming.

Nance, D.R., Smith, C.W., Smithson, C.W., 1993. On the Determinants of Corporate Hedging. Journal of Finance 48(1), 267-284.

Nguyen, H., Faff, R., 2003. Can the use of foreign currency derivatives explain variations in foreign exchange exposure? Evidence from Australian companies. Journal of Multinational Financial Management 13, 193-215. 
Table 1

Summary of main U.S. trade partners in insurance

\begin{tabular}{|c|c|c|c|c|c|c|c|}
\hline & \multicolumn{2}{|c|}{2001} & \multicolumn{2}{|c|}{2002} & \multicolumn{2}{|c|}{ Average } & \multirow[b]{2}{*}{ Total Insurance Activity } \\
\hline & Inflows & Outflows & Inflows & Outflows & Inflows & Outflows & \\
\hline $\begin{array}{l}\text { United Kingdom } \\
\text { nom }\end{array}$ & 5,126 & 40,710 & 9,964 & 47389 & 7,095 & 444,050 & 51,145 \\
\hline Japan & 12,909 & 23,698 & 9,097 & 29,338 & 11,003 & 26,518 & 37,521 \\
\hline Germany & 15,880 & 13,300 & 10,443 & 13,264 & 13,162 & 13,282 & 26,444 \\
\hline Switzerland & 22,114 & 4,125 & 16,766 & 4,748 & 19,440 & 4,437 & 23,877 \\
\hline Netherlands & 35,569 & 640 & 34,768 & 5449 & 35,169 & 3,045 & 38,213 \\
\hline France & 28,873 & 2,283 & 32,015 & 2,183 & 30,444 & 2,233 & 32,677 \\
\hline Canada & 25,289 & 26,055 & 25,332 & 23,498 & 25,311 & 24,777 & 50,087 \\
\hline Total & 145,760 & 110,811 & 137,485 & 125,869 & 141,623 & 118,340 & 259,963 \\
\hline All Countries & 174,109 & 225,556 & 162,853 & 244,480 & 168,481 & 235,018 & 403,499 \\
\hline
\end{tabular}




\section{Table 2}

\section{Summary of currency exposure in the U.S. insurance industry}

This table presents a summary of the numbers and proportions of non-broker US insurers that are significantly exposed to the currencies of the industry's major trading partners. In Panel A, the significantly exposed non-life and life insurance companies are shown. In Panel B the significantly exposed domestic and international insurers are presented. In Panel $\mathrm{C}$, the significantly exposed small and large insurance companies are finally shown. The $\mathrm{Z}$ test statistics are computed for comparing two proportions where *, ** and *** represent the $10 \%, 5 \%$ and $1 \%$ levels of significance for a one-tail test respectively.

\begin{tabular}{|c|c|c|c|c|}
\hline \multicolumn{5}{|c|}{ Panel A: exposures of non-life and life insurers } \\
\hline Currency & $\begin{array}{c}\text { All Insurers } \\
(\mathrm{N}=73)\end{array}$ & $\begin{array}{c}\text { Non-Life } \\
(\mathrm{N}=60)\end{array}$ & $\begin{array}{c}\text { Life } \\
(\mathrm{N}=13)\end{array}$ & $\mathrm{Z}_{\text {Non-Life }>\text { Life. }}$ \\
\hline$\overline{\mathrm{UK}}$ & $53(73 \%)$ & $42(70 \%)$ & $11(85 \%)$ & -1.07 \\
\hline JAP & $52(71 \%)$ & $44(73 \%)$ & $8(62 \%)$ & 0.85 \\
\hline SWZ & 37 (51\%) & $31(52 \%)$ & $6(46 \%)$ & 0.36 \\
\hline NETH & $31(42 \%)$ & $27(45 \%)$ & $4(31 \%)$ & 0.94 \\
\hline FRA & $40(55 \%)$ & $34(57 \%)$ & $6(46 \%)$ & 0.69 \\
\hline GER & $43(59 \%)$ & $36(60 \%)$ & $7(54 \%)$ & 0.41 \\
\hline CAN & $27(37 \%)$ & $22(37 \%)$ & $5(38 \%)$ & -0.12 \\
\hline \multicolumn{5}{|c|}{ Panel B: exposures of domestic and international insurers } \\
\hline Currency & $\begin{array}{c}\text { All Insurers } \\
(\mathrm{N}=73)\end{array}$ & $\begin{array}{c}\text { Domestic } \\
(\mathrm{N}=61)\end{array}$ & $\begin{array}{c}\text { International } \\
(\mathrm{N}=12)\end{array}$ & $\mathrm{Z}_{\text {Dom>Intl. }}$ \\
\hline UK & $53(73 \%)$ & $48(79 \%)$ & $5(42 \%)$ & $2.63 * * *$ \\
\hline JAP & $52(71 \%)$ & $45(74 \%)$ & $7(58 \%)$ & 1.08 \\
\hline SWZ & 37 (51\%) & $31(51 \%)$ & $6(50 \%)$ & 0.05 \\
\hline NETH & $31(42 \%)$ & $28(46 \%)$ & $3(25 \%)$ & $1.34 *$ \\
\hline FRA & 40 (55\%) & $34(56 \%)$ & $6(50 \%)$ & 0.37 \\
\hline GER & 43 (59\%) & 37 (61\%) & $6(50 \%)$ & 0.69 \\
\hline CAN & 27 (37\%) & 24 (39\%) & $3(25 \%)$ & 0.94 \\
\hline \multicolumn{5}{|c|}{ Panel C: exposures of small and large insurers } \\
\hline Currency & $\begin{array}{l}\text { All Insurers } \\
(\mathrm{N}=73)\end{array}$ & $\begin{array}{l}\text { Small } \\
(\mathrm{N}=32)\end{array}$ & $\begin{array}{l}\text { Large } \\
(\mathrm{N}=41)\end{array}$ & $Z_{\text {Sm>Lge. }}$ \\
\hline$\overline{\text { UK }}$ & $53(73 \%)$ & $24(75 \%)$ & $29(71 \%)$ & 0.41 \\
\hline JAP & 52 (71\%) & $23(72 \%)$ & $29(71 \%)$ & 0.11 \\
\hline SWZ & 37 (51\%) & 20 (63\%) & 17 (41\%) & $1.78 * *$ \\
\hline NETH & 31 (42\%) & $14(44 \%)$ & $17(41 \%)$ & 0.20 \\
\hline FRA & 40 (55\%) & $16(50 \%)$ & 24 (59\%) & -0.73 \\
\hline GER & 43 (59\%) & 18 (56\%) & 25 (61\%) & -0.41 \\
\hline CAN & 27 (37\%) & 17 (53\%) & $10(24 \%)$ & $2.52^{* * *}$ \\
\hline
\end{tabular}




\section{Table 3}

\section{Time horizon effect on currency exposure of U.S. insurers}

This table represents the number of significant insurers out of the total and sub-samples found to have the optimal number of lags within the defined time frame. Here, long term is defined to consist of 8 quarters or more ( $\geq 2$ years) and short term is defined to consist of 4 quarters or less ( $\leq 1$ year). Comparisons between samples are based on the Z-test statistic of population proportions where $*$, ** and $* * *$ represent the $10 \%, 5 \%$ and $1 \%$ levels of significance respectively.

\begin{tabular}{|c|c|c|c|c|c|c|c|}
\hline & \multicolumn{7}{|c|}{ Currency } \\
\hline & UK & JAP & SWZ & NETH & FRA & GER & CAN \\
\hline \multicolumn{8}{|c|}{ All insurers $(N=73)$} \\
\hline Short-term & $\begin{array}{c}20 \text { of } 39 \\
(51 \%)\end{array}$ & $\begin{array}{c}10 \text { of } 30 \\
(33 \%)\end{array}$ & $\begin{array}{c}16 \text { of } 52 \\
(31 \%)\end{array}$ & $\begin{array}{c}11 \text { of } 52 \\
(21 \%)\end{array}$ & $\begin{array}{c}13 \text { of } 45 \\
(29 \%)\end{array}$ & $\begin{array}{c}17 \text { of } 47 \\
(36 \%)\end{array}$ & $\begin{array}{c}11 \text { of } 55 \\
(20 \%)\end{array}$ \\
\hline Long-term & $\begin{array}{c}14 \text { of } 24 \\
(58 \%)\end{array}$ & $\begin{array}{c}18 \text { of } 29 \\
(62 \%)\end{array}$ & $\begin{array}{c}3 \text { of } 14 \\
(21 \%)\end{array}$ & $\begin{array}{c}9 \text { of } 17 \\
(53 \%)\end{array}$ & $\begin{array}{c}8 \text { of } 14 \\
(57 \%)\end{array}$ & $\begin{array}{c}9 \text { of } 16 \\
(56 \%)\end{array}$ & $\begin{array}{c}6 \text { of } 14 \\
(43 \%)\end{array}$ \\
\hline $\mathrm{Z}_{\text {long>short }}$ & 0.55 & $2.21^{* *}$ & -0.69 & $2.51^{* * *}$ & $1.93^{* *}$ & $1.41^{*}$ & $1.77 * *$ \\
\hline \multicolumn{8}{|c|}{ Dom. Insurers $(N=61)$} \\
\hline Short-term & $\begin{array}{c}18 \text { of } 31 \\
(58 \%)\end{array}$ & $\begin{array}{c}8 \text { of } 23 \\
(35 \%)\end{array}$ & $\begin{array}{c}13 \text { of } 43 \\
(30 \%)\end{array}$ & $\begin{array}{c}8 \text { of } 40 \\
(20 \%)\end{array}$ & $\begin{array}{c}11 \text { of } 37 \\
(30 \%)\end{array}$ & $\begin{array}{c}15 \text { of } 39 \\
(38 \%)\end{array}$ & $\begin{array}{c}9 \text { of } 44 \\
(20 \%)\end{array}$ \\
\hline Long-term & $\begin{array}{c}13 \text { of } 23 \\
(57 \%)\end{array}$ & $\begin{array}{c}16 \text { of } 25 \\
(64 \%)\end{array}$ & $\begin{array}{c}3 \text { of } 12 \\
(25 \%)\end{array}$ & $\begin{array}{l}9 \text { of } 17 \\
(53 \%)\end{array}$ & $\begin{array}{c}8 \text { of } 13 \\
(62 \%)\end{array}$ & $\begin{array}{c}8 \text { of } 13 \\
(62 \%)\end{array}$ & $\begin{array}{c}6 \text { of } 14 \\
(43 \%)\end{array}$ \\
\hline $\mathrm{Z}_{\text {long>short }}$ & -0.11 & $2.02 * *$ & -0.35 & $2.49 * * *$ & $2.03 * *$ & $1.45^{*}$ & $1.67 * *$ \\
\hline \multicolumn{8}{|c|}{ Intl. Insurers $(N=12)$} \\
\hline Short & $\begin{array}{l}2 \text { of } 8 \\
(25 \%)\end{array}$ & $\begin{array}{l}2 \text { of } 7 \\
(29 \%)\end{array}$ & $\begin{array}{l}3 \text { of } 9 \\
(33 \%)\end{array}$ & $\begin{array}{c}3 \text { of } 12 \\
(25 \%)\end{array}$ & $\begin{array}{l}2 \text { of } 8 \\
(25 \%)\end{array}$ & $\begin{array}{l}2 \text { of } 8 \\
(25 \%)\end{array}$ & $\begin{array}{l}2 \text { of } 11 \\
(18 \%)\end{array}$ \\
\hline Long-term & $\begin{array}{c}1 \text { of } 1 \\
(100 \%)\end{array}$ & $\begin{array}{l}2 \text { of } 4 \\
(50 \%)\end{array}$ & $\begin{array}{l}0 \text { of } 2 \\
(0 \%)\end{array}$ & $\begin{array}{l}0 \text { of } 0 \\
(0 \%)\end{array}$ & $\begin{array}{l}0 \text { of } 1 \\
(0 \%)\end{array}$ & $\begin{array}{l}1 \text { of } 3 \\
(33 \%)\end{array}$ & $\begin{array}{c}0 \text { of } 0 \\
(0 \%)\end{array}$ \\
\hline $\mathrm{Z}_{\text {long }>\text { short }}$ & $1.50^{*}$ & 0.71 & -0.96 & - & -0.57 & 0.28 & - \\
\hline \multicolumn{8}{|c|}{ Small insurers $(N=32)$} \\
\hline Short-term & $\begin{array}{c}10 \text { of } 18 \\
(56 \%)\end{array}$ & $\begin{array}{c}6 \text { of } 14 \\
(43 \%)\end{array}$ & $\begin{array}{c}8 \text { of } 20 \\
(40 \%)\end{array}$ & $\begin{array}{c}2 \text { of } 19 \\
(11 \%)\end{array}$ & $\begin{array}{c}6 \text { of } 21 \\
(29 \%)\end{array}$ & $\begin{array}{c}6 \text { of } 20 \\
(30 \%)\end{array}$ & $\begin{array}{c}8 \text { of } 22 \\
(36 \%)\end{array}$ \\
\hline Long-term & $\begin{array}{l}6 \text { of } 11 \\
(55 \%)\end{array}$ & $\begin{array}{c}9 \text { of } 12 \\
(75 \%)\end{array}$ & $\begin{array}{l}1 \text { of } 7 \\
(14 \%)\end{array}$ & $\begin{array}{l}5 \text { of } 11 \\
(45 \%)\end{array}$ & $\begin{array}{l}3 \text { of } 6 \\
(50 \%)\end{array}$ & $\begin{array}{l}3 \text { of } 7 \\
(43 \%)\end{array}$ & $\begin{array}{l}2 \text { of } 7 \\
(29 \%)\end{array}$ \\
\hline $\mathrm{Z}_{\text {long>short }}$ & -0.05 & $1.65^{* *}$ & -1.24 & $2.18^{* *}$ & 0.98 & 0.62 & -0.38 \\
\hline \multicolumn{8}{|c|}{ Large Insurers $(N=41)$} \\
\hline Short-term & $\begin{array}{l}10 \text { of } 21 \\
(48 \%)\end{array}$ & $\begin{array}{l}4 \text { of } 16 \\
(25 \%)\end{array}$ & $\begin{array}{l}8 \text { of } 32 \\
(25 \%)\end{array}$ & $\begin{array}{l}9 \text { of } 33 \\
(27 \%)\end{array}$ & $\begin{array}{l}7 \text { of } 24 \\
(29 \%)\end{array}$ & $\begin{array}{c}11 \text { of } 27 \\
(41 \%)\end{array}$ & $\begin{array}{l}3 \text { of } 33 \\
(9.1 \%)\end{array}$ \\
\hline Long-term & $\begin{array}{l}8 \text { of } 13 \\
(62 \%)\end{array}$ & $\begin{array}{l}9 \text { of } 17 \\
(53 \%)\end{array}$ & $\begin{array}{l}2 \text { of } 7 \\
(29 \%)\end{array}$ & $\begin{array}{l}4 \text { of } 6 \\
(67 \%)\end{array}$ & $\begin{array}{l}5 \text { of } 8 \\
(63 \%)\end{array}$ & $\begin{array}{l}6 \text { of } 9 \\
(67 \%)\end{array}$ & $\begin{array}{l}4 \text { of } 7 \\
(57 \%)\end{array}$ \\
\hline $\mathrm{Z}_{\text {long }>\text { short }}$ & 0.79 & $1.64^{*}$ & 0.2 & $1.88^{* *}$ & $1.69 * *$ & $1.35 *$ & $3.04 * * *$ \\
\hline
\end{tabular}

